\title{
EFEKTIVITAS MODEL PROJECT BASED LEARNING (PBL) DALAM MENINGKATKAN KEMAMPUAN PEMECAHAN MASALAH MATEMATIS
}

\section{THE EFFECTIVENESS OF PROJECT BASED LEARNING (PBL) MODEL IN IMPROVING MATHEMATICS PROBLEM SOLVING ABILITY}

\author{
Lenny Sasmita1), Thamrin Tayeb2), Lisnasari Andi Mattoliang3), Andi Ika Prasasti \\ Abrar4), Mardhiah'5) \\ 1,2,3,4,5)Fakultas Tarbiyah dan Keguruan, Universitas Islam Negeri Alauddin Makassar \\ lenny.sasmita@gmail.com ${ }^{1}$, thamrin.tayeb@uin-alauddin.ac.id ${ }^{2}$ ), lisnasari.mattoliang@uin- \\ alauddin.ac.id ${ }^{3)}$, ika.prasastiabrar@uin-alauddin.ac.id ${ }^{4}$,,$\underline{\text { dhiah612@gmail.com }}{ }^{5)}$
}

\begin{abstract}
Abstrak
Tujuan penelitian ini adalah untuk mengetahui efektivitas penerapan model pembelajaran project based learning dalam meningkatkan kemampuan pemecahan masalah matematis peserta didik. Pendekatan penelitian ini adalah pendekatan kuantitatif dengan jenis penelitian eksperimen semu yang didesain menggunakan teknik Non-Equivalent Control Group Design. Sampel penelitian adalah peserta didik kelas VIII MTs Negeri Model Makassar. Teknik analisis data menggunakan analisis deskriptif dan inferensial. Hasil penelitian menunjukkan bahwa 1) kelas eksperimen sebelum menerapkan model pembelajaran project based learning memperoleh nilai rata-rata hasil tes kemampuan pemecahan masalah sebesar 79,28. Setelah menerapkan model pembelajaran project based learning diperoleh nilai rata-rata hasil tes kemampuan pemecahan masalah sebesar 91,24 sehingga terjadi peningkatan rata-rata sebesar 15,086\%;2) secara signifikan, terjadi peningkatan kemampuan pemecahan masalah untuk kelas yang menggunakan model pembelajaran project based learning di MTs Negeri Model Makassar.
\end{abstract}

Kata Kunci: project based learning, kemampuan pemecahan masalah

\begin{abstract}
This research was conducted to determine the effectiveness of the application of the project based learning model in improving students' mathematical problem solving abilities. This research approach is a quantitative approach with a quasi-experimental type of research designed using the Non-Equivalent Control Group Design technique. The research sample was class VIII MTs Negeri Model Makassar.. The data analysis technique used descriptive and inferential analysis, namely $t$ test. The results showed that 1) the experimental class before applying the project-based learning model obtained an average value of the problem-solving ability test results of 79.28. After applying the project based learning learning model, the average value of the problem solving ability test results was 91.24, resulting in an average increase of $15.086 \%$; 2) there is a significant increase in problem-solving abilities for classes that use the project-based learning model at MTs Negeri Model Makassar.
\end{abstract}

Keywords: project based learning, problem solving ability

How to Cite: Sasmita, L., Tayeb, T., Mattoliang, L. A., Abrar, A. I. P., \& Mardhiah. (2021). Efektivitas model Project Based Learning (PBL) dalam meningkatkan kemampuan pemecahan masalah matematis. Al asma: Journal of Islamic Education, 3(2), 242-249. 


\section{PENDAHULUAN}

Dalam kehidupan manusia, pendidikan menjadi hal pokok yang memiliki urgensi dalam menjalani kehidupan, sehingga pendidikan dalam kehidupan, baik itu kehidupan keluarga, atau kehidupan bangsa dan negara adalah hal yang tidak dapat dipisahkan. Maju mundurnya sebuah bangsa, ditentukan oleh pendidikan di negara tersebut (Ahmadi \& Uhbiyati, 2003). Untuk tercapainya tujuan pendidikan, maka upaya yang dapat dilakukan adalah melaksanakan proses pembelajaran untuk membantu peserta didik menjadi sumber daya manusia berkualitas. Adapun pembelajaran yang diharapkan adalah pembelajaran yang efisien dan efektif untuk peserta didik (Setyosari, 2014) dan bukan pembelajaran yang monoton. Sebab pembelajaran yang monoton akan mempengaruhi semangat belajar dan prestasi peserta didik.

Menciptakan pembelajaran yang ideal dapat dilakukan melalui pemilihan strategi juga model pembelajaran yang relevan. Pemilihan ini dapat didasari dengan standar kompetensi yang diharapkan dapat dicapai oleh peserta didik sehingga selain memberi hasil belajar yang memenuhi standar juga dapat memacu kemampuan pemecahan masalah peserta didik. Hal ini demi tercapainya optimalisasi kualitas pembelajaran dan pembelajaran yang bermakna (Jalinus, Nabawi, \& Mardin, 2017; Solikah \& Himmah, 2019).

Kemampuan pemecahan masalah merupakan salah satu kemampuan berpikir tingkat tinggi (Prabawa \& Zaenuri, 2017). Berdasarkan teori belajar yang dikemukakan oleh Gagne, sejalan dengan apa yang diungkapkan oleh Prabawa \& Zaenuri, bahwa pemecahan masalah dapat dikembangkan dengan memiliki kemampuan keterampilan intelektual yang tinggi (Robert M. Gagne, Leslie J. Briggs, 1992). Sumber daya manusia yang berkualitas memiliki kemampuan pemecahan masalah yang tinggi, dari menyelesaikan masalah yang paling ringan hingga yang paling rumit. Kemampuan pemecahan masalah dapat dimiliki dengan memiliki kemampuan berpikir tingkat tinggi (Putriari, 2013).

Berdasarkan hasil wawancara di MTs Negeri Model Makassar, seorang guru mengemukakan bahwa pembelajaran yang berlangsung masih menggunakan model biasa atau ceramah. Khususnya pada mata pelajaran matematika, dimana guru fokus menjelaskan materi dan peserta didik hanya menerima apa yang disampaikan oleh guru. Peserta didik tidak dituntut untuk memperoleh materi secara mandiri, sehingga potensi dan kreativitasnya tidak dapat berkembang dengan baik. Padahal secara ideal, peserta didik diharapkan mampu untuk berpikir kreatif juga analitis. Peserta didik mampu mengembangkan ide-ide yang baru terkait permasalahan yang ada di sekitarnya sehingga mampu memecahkan masalah tersebut. Oleh karena itu, untuk menciptakan suasana pembelajaran yang sesuai, dimana peserta didik tidak lagi pasif dalam pembelajaran, maka peneliti tertarik untuk menerapkan suatu model pembelajaran yang inovatif.

Salah satu model pembelajaran yang dianjurkan untuk digunakan dan dipilih peneliti guna mendukung pembelajaran adalah Project Based Learning (PBL) (Ismuwardani, Nuryatin, \& Doyin, 2019). Menurut Nurfitriyanti (2016), model PBL diduga efektif digunakan untuk meningkatkan kemampuan pemecahan masalah matematis peserta didik. Meskipun PBL sudah ada sejak dulu, akan tetapi realisasi di dalam kelas khususnya matematika masih kurang di sekolah-sekolah.

Kelebihan model PBL adalah dapat membuat pengalaman belajar yang lebih menarik dan bermakna (Zakiah, Fatimah, \& Sunaryo, 2020), menyediakan fasilitas peserta 
didik untuk menyelidiki suatu hal, memecahkan masalah, bersifat students centered, dan menghasilkan produk nyata berupa hasil proyek (Riyanti, Erwin, \& Suriani, 2017). Secara otentik, produk yang dihasilkan dapat dinilai oleh guru di dalam pembelajaran, sehingga kedudukan guru di dalam model ini adalah pendamping dan fasilitator. Guru melatih secara langsung dan memahami pikiran peserta didik (Khanah, Rasiman, \& Sutrisno, 2019).

Penelitian model project based learning sebelumnya telah banyak dilakukan, yaitu Nusa (2021) dalam penelitiannya menerapkan model project based learning untuk melihat keefektifan model tersebut pada mata kuliah Vulkanologi. Hasil penelitiannya menunjukkan bahwa hasil belajar kelas eksperimen lebih tinggi dibanding hasil belajar konvensional. Selain itu penelitian Kiswanto (2019) juga mengemukakan bahwa penggunaan model project based learning di sekolah mampu meningkatkan kemampuan koneksi matematis peserta didik.

Dari uraian di atas, sangat menarik dan penting untuk dilakukan suatu penelitian mengenai penerapan project based learning dalam pembelajaran matematika yang dituangkan dalam judul "Efektivitas Model Project Based Learning dalam Meningkatkan Kemampuan Pemecahan Masalah Matematis Peserta Didik Kelas VIII MTs Negeri Model Makassar."

\section{METODE PENELITIAN}

Penelitian ini menggunakan pendekatan kuantitatif, dengan jenis penelitian eksperimen semu. Populasi penelitian adalah peserta didik kelas VIII MTs Negeri Model yang terdiri atas 11 kelas dengan total 440 peserta didik. Teknik pengambilan sampel menggunakan teknik random sampling. Sampel yang terpilih adalah kelas VIII-4 yang terdiri dari 40 orang peserta didik sebagai kelas kontrol dan kelas VIII-5 yang terdiri dari 39 peserta didik sebagai kelas eksperimen. Desain penelitian yang digunakan adalah Nonequivalent Control Group Design. Desain penelitian dapat dilihat sebagaimana gambar di bawah ini .

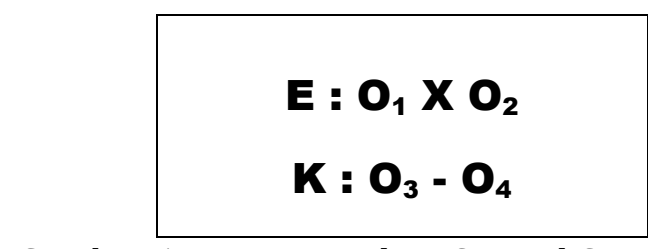

Gambar 1. Non-equivalent Control Group Design

Sumber: (Sugiyono, 2010)

Keterangan:

E : Kelompok eksperimen

K : Kelompok kontrol

X $\quad$ : Perlakuan dengan model Project Based Learning

- $\quad$ : Tanpa perlakuan

01 : Hasil Pretest kelas eksperimen

O2 : Hasil Posttest kelas eksperimen

O3 : Hasil Pretest kelas kontrol

04 : Hasil Posttest kelas kontrol 
Pengumpulan data dilakukan dengan menggunakan teknik observasi, tes, dan dokumentasi. Observasi digunakan untuk mengamati aktivitas peserta didik yang menggunakan model PBL. Metode tes digunakan untuk memperoleh data tentang kemampuan pemecahan masalah peserta didik. Tes diberikan kepada kedua kelas dengan instrumen yang sama sebelum dan setelah pelaksanaan pembelajaran. Terlebih dahulu tes diujicobakan untuk mendapat soal yang baik yaitu soal yang valid, reliabel, memiliki kesukaran yang proporsional, dan daya pembeda yang signifikan. Dokumentasi digunakan dalam penelitian ini untuk mendapatkan data mengenai hasil belajar matematika dalam hal kemampuan pemecahan masalah matematis. Untuk mengolah data hasil penelitian, maka peneliti menggunakan teknik analisis statistika deskriptif dan statistika inferensial. Dalam statistika inferensial digunakan uji hipotesis yaitu uji t.

\section{HASIL DAN PEMBAHASAN}

\section{Deskripsi Hasil Penelitian}

Berdasarkan hasil penelitian, diperoleh hasil tes kemampuan pemecahan masalah matematis kelas eksperimen sebelum dan setelah menerapkan model PBL, sebagai berikut.

Tabel 1. Nilai Statistik Deskriptif Hasil Pre-test dan Post-test pada Kelas Eksperimen

\begin{tabular}{ccc}
\hline \multirow{2}{*}{ Statistik } & \multicolumn{2}{c}{ Nilai Statistik } \\
\cline { 2 - 3 } & Pre-Test & Post-Test \\
\hline Sampel & 39 & 39 \\
Nilai Terendah & 40 & 75 \\
Nilai Tertinggi & 100 & 100 \\
Nilai rata-rata $(\bar{x})$ & 79,28 & 91,46 \\
Standar Deviasi & 10,44 & 6,8 \\
\hline
\end{tabular}

Pada tabel 1 diketahui nilai rata-rata hasil pre-test ke post-test untuk kelas eksperimen meningkat, yaitu dari 79,28 ke 91,46 dengan selisih 12,18. Hal ini menunjukkan bahwa rata-rata kemampuan pemecahan masalah peserta didik setelah menerapkan model project based learning meningkat sebelum diterapkan model project based learning.

Adapun data hasil tes kemampuan pemecahan masalah matematis peserta didik yang tidak menggunakan model PBL pada kelas kontrol dapat dilihat pada tabel 2 .

Tabel 2. Nilai Statistik Deskriptif Hasil Pre-test dan Post-test pada Kelas Kontrol

\begin{tabular}{ccc}
\hline \multirow{2}{*}{ Statistik } & \multicolumn{2}{c}{ Nilai Statistik } \\
\cline { 2 - 3 } & Pre-Test & Post-Test \\
\hline Sampel & 40 & 40 \\
Nilai Terendah & 40 & 40 \\
Nilai Tertinggi & 95 & 95 \\
Nilai rata-rata $(\bar{x})$ & 76,95 & 77,13 \\
Standar Deviasi & 9,54 & 9,6 \\
\hline
\end{tabular}

Pada tabel 2 diketahui bahwa rata-rata hasil pre-test ke post-test untuk kelas kontrol meningkat, yaitu dari 76,95 ke 77,13 dengan selisih 0,18. Selisih ini tidak mencapai penambahan 1 poin, sehingga secara peningkatan kelas yang tidak menerapkan 
model PBL tidak banyak memberikan peningkatan hasil rata-rata kemampuan pemecahan masalah matematis peserta didik.

Berdasarkan perhitungan sebelumnya diketahui bahwa rata-rata hasil tes kemampuan pemecahan masalah peserta didik pada kelas eksperimen yang diajar dengan menggunakan model PBL adalah 79,28 untuk pre-test dan 91,46 untuk post-test. Sedangkan rata-rata hasil tes kemampuan pemecahan masalah peserta didik pada kelas kontrol yang tidak diajar dengan menggunakan model PBL adalah 76,95 untuk pre-test dan 77,13 untuk post-test.

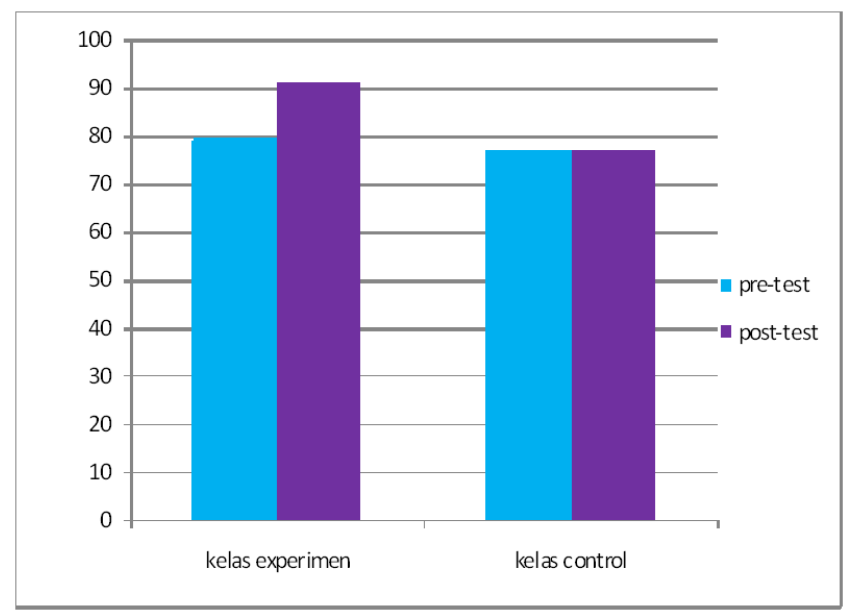

Gambar 2. Perbandingan rata-rata Hasil Tes Kemampuan Pemecahan Masalah Matematis Kelas Eksperimen dan Kelas Kontrol

\section{Uji Hipotesis}

Uji asumsi pada penelitian ini yaitu uji normalitas dan homogenitas. Hal ini dilakukan sebab uji t yang digunakan untuk menjawab hipotesis penelitian adalah salah satu uji parametrik yang sangat ketat akan asumsi. Dengan demikian, sebelum melakukan uji hipotesis, terlebih dahulu asumsi uji t terpenuhi.

Berdasarkan uji asumsi diperoleh bahwa data post-test kelas eksperimen dan kelas kontrol berdistribusi normal dan berdasarkan uji homogenitas diperoleh bahwa data dari kedua kelompok berasal dari populasi yang homogen.

Hipotesis atau dugaan sementara dalam penelitian ini, dirumuskan oleh penulis sebagai berikut.

$$
\mathrm{H}_{\mathrm{o}}: \mu_{1}=\mu_{2} \text { melawan } \mathrm{H}_{1}: \mu_{1} \neq \mu_{2}
$$

$\mathrm{H}_{\mathrm{o}}$ : Penerapan model Project Based Learning (PBL) tidak efektif dalam meningkatkan kemampuan pemecahan masalah matematis peserta didik kelas VIII MTs Negeri Model Makassar

$\mathrm{H}_{1}$ : Penerapan model Project Based Learning (PBL) efektif dalam meningkatkan kemampuan pemecahan masalah matematis peserta didik kelas VIII MTs Negeri Model Makassar.

$\mu_{1}$ : Rata-rata hasil kemampuan pemecahan masalah matematis peserta didik yang menerapkan model Project Based Learning (PBL)

$\mu_{2}$ : Rata-rata hasil kemampuan pemecahan masalah matematis peserta didik tanpa menerapkan model Project Based Learning (PBL) 
Kriteria pengujian hipotesis yaitu:

- Ho ditolak jika t hitung $>\mathrm{t}$ tabel.

- Ho diterima jika t hitung $<\mathrm{t}$ tabel.

Untuk menjawab hipotesis, maka menggunakan uji sign (uji t). Berdasarkan analisis, maka diketahui t-hitung sebesar 7,484 dan t-tabel sebesar 1,67. Berdasarkan kriteria, disimpulkan bahwa t-hitung > t-tabel $(7,484>1,67)$, sehingga Ho ditolak. Hasil ini menunjukkan bahwa kemampuan pemecahan masalah matematis peserta didik yang menggunakan model pembelajaran project based learning dengan peserta didik yang tidak diajar dengan menggunakan model project based learning berbeda secara signifikan pada kelas VIII MTs Negeri Model Makassar.

\section{Pembahasan}

Rendahnya rata-rata nilai hasil tes kemampuan pemecahan masalah peserta didik pada kelas yang tidak menerapkan model PBL disebabkan kurangnya media atau alat bantu untuk membantu peserta didik dalam menyelesaikan soal-soal. Selain itu, peserta didik merasa kurang tertarik dan termotivasi untuk belajar, karena model pembelajaran yang diterapkan kurang menarik. Pada kelas kontrol hanya menggunakan pedoman buku teks kemudian mempelajari contoh soal yang diberikan, sehingga mengakibatkan pengetahuan peserta didik tidak mendukung untuk menyelesaikan soal-soal. Sebagaimana yang diungkapkan oleh Mahayani, Irwandani, Yuberti, \& Widayanti (2018) bahwa penggunaan media dalam pemecahan masalah dapat menarik minat peserta didik dalam proses pembelajaran.

Hal yang berbeda terjadi pada peserta didik yang diajar dengan menggunakan model project based learning, peserta didik memperoleh rata-rata kemampuan pemecahan masalah matematis yang tinggi. Hal ini disebabkan karena dalam pembelajaran mereka diberikan pengalaman belajar yang menarik (Octaviyani, Kusumah, \& Hasanah, 2020). Pada model pembelajaran ini pembelajaran dirancang dalam bentuk kelompok dengan diberikan suatu contoh masalah. Dengan adanya pembelajaran seperti ini, peserta didik akan lebih aktif untuk menggali potensi pengetahuan, misalnya dalam menyampaikan pendapat, presentasi hasil proyek, dan menanggapi hasil proyek yang dipresentasikan oleh temannya. Hal ini sejalan dengan yang diungkapkan oleh Khanah, Rasiman, dan Sutrisno (2019) bahwa peserta didik menjadi lebih aktif, baik dalam hal bekerja sama, apersepsi, dan mempresentasikan proyek yang telah dibuat melalui model project based learning, sehingga dapat mempengaruhi kemampuan pemecahan masalah peserta didik, dimana hasil tes kemampuan pemecahan masalah matematis peserta didik yang diajar dengan menggunakan model project based learning memiliki rata-rata 91,46. Hasil ini juga didukung oleh hasil analisis pada lembar observasi yang menunjukkan aktivitas belajar peserta didik cukup efektif.

Adapun hasil uji hipotesis menunjukkan bahwa model project based learning signifikan dalam meningkatkan kemampuan pemecahan masalah peserta didik dibanding tidak menggunakan model project based learning. Hasil penelitian serupa juga diungkapkan oleh Nurfitriyanti (2016) bahwa penggunaan model project based learning lebih baik dalam meningkatkan kemampuan pemecahan masalah matematis peserta didik dibanding dengan menggunakan model pembelajaran ekspositori. 
Pada pembelajaran berbasis proyek, peserta didik diberi kesempatan untuk bebas berekplorasi dalam kegiatan pembelajaran, merencanakan proyek, dan menghasilkan suatu produk berdasarkan kerja sama tim. Hal ini sejalan dengan yang diungkapkan oleh Kristiyanto (2020) bahwa tujuan PBL adalah meningkatkan berbagai kemampuan intelektual, sosial, emosional, dan moral. Selain itu, peserta didik mampu bekerja secara mandiri sehingga pengetahuannya dapat terkonstruk dengan baik dan menuangkannya dalam sebuah produk yang nyata. Pernyataan ini juga didukung oleh Tong, Kinshuk, dan Wei (2020) bahwa project based learning adalah seperangkat prinsip berdasarkan pandangan konstruktivis belajar yang mengedepankan bahwa orang secara aktif membangun pengetahuan daripada menerima dan menyimpannya.

Berdasarkan hasil penelitian tersebut dapat dilihat bahwa penggunaan model PBL lebih baik dalam meningkatkan nilai hasil belajar peserta didik daripada model pembelajaran tradisional.

\section{SIMPULAN}

Hasil penelitian ini menyimpulkan beberapa hal, yaitu: (1) kelas eksperimen sebelum menerapkan model project based learning memperoleh nilai rata-rata hasil tes kemampuan pemecahan masalah sebesar 79,28. Setelah menerapkan model pembelajaran project based learning memperoleh nilai rata-rata hasil tes kemampuan pemecahan masalah sebesar 91,24, sehingga terjadi peningkatan rata-rata sebesar 15,086\%; (2) secara signifikan terjadi peningkatan kemampuan pemecahan masalah untuk kelas yang menggunakan model project based learning di MTs Negeri Model Makassar.

Penerapan model PBL efektif dalam meningkatkan kemampuan pemecahan masalah matematis peserta didik kelas VIII MTs Negeri Model Makassar. Bagi guru yang ingin mengembangkan kemampuan pemecahan masalah matematis peserta didik hendaknya mengimplemetasikan model PBL ini sebagai alternatif usaha perbaikan pembelajaran di sekolah.

\section{DAFTAR PUSTAKA}

Ahmadi, A., \& Uhbiyati, N. (2003). Ilmu pendidikan. Jakarta: Rineka Cipta.

Emzir. (2014). Metodologi penelitian pendidikan kuantitatif dan kualitatif. Jakarta: Rajawali Pers.

Ismuwardani, Z., Nuryatin, A., \& Doyin, M. (2019). Implementation of project based learning model to increased creativity and self-reliance of students on poetry writing skills. Journal of Primary Education, 8(40), 51-58.

Jalinus, N., Nabawi, R. A., \& Mardin, A. (2017). The seven steps of project based learning model to enhance productive competences of vocational students. Advances in Social Science, Education and Humanities Research, 102(Ictvt), 251-256.

Khanah, N., Rasiman, \& Sutrisno. (2019). Efektivitas model project based learning dan model discovery learning berbantuan macromedia flash terhadap prestasi belajar matematika siswa kelas VIII. Seminar Nasional Matematika dan Pendidikan Matematika (4thSENATIK) Program Studi Pendidikan Matematika, 135-145.

Kiswanto, A. (2019). Peningkatan kemampuan koneksi matematis siswa Sekolah Dasar melalui model Project Based Learning. Pros. SemNas. Peningkatan Mutu Pendidikan, 1, 131-136. $\quad$ http://publikasi.fkipunsam.org/index.php/semnas2019/article/view/34 
Kristiyanto, D. (2020). Peningkatan kemampuan berpikir kritis dan hasil belajar matematika dengan model Project Based Learning (PJBL). Jurnal Mimbar Ilmu, 25(1), 1-10.

Mahayani, S., Irwandani, I., Yuberti, Y., \& Widayanti, W. (2018). Kotak pop-up berbasis problem solving: pengembangan media pembelajaran pada materi cahaya dan alat-alat optik untuk kelas VIII SMP. Jurnal Pendidikan Matematika Dan IPA, 9(2), 98. https://doi.org/10.26418/jpmipa.v9i2.25847

Nurfitriyanti, M. (2016). Model pembelajaran project based learning terhadap kemampuan pemecahan masalah matematika. Jurnal Formatif, 6(2), 149-160.

Nusa, J. G. N. (2021). Efektivitas model project based learning pada mata kuliah vulkanologi terhadap hasil belajar mahasiswa. Jurnal Ilmiah Mandala Education, $7(2), 210-214$.

Octaviyani, I., Kusumah, Y. S., \& Hasanah, A. (2020). Peningkatan kemampuan berpikir kreatif matematis siswa melalui model project-based learning dengan pendekatan STEM. Journal on Mathematics Education Research, 1(1), 10-14.

Prabawa, E. A., \& Zaenuri. (2017). Analisis kemampuan pemecahan masalah ditinjau dari gaya kognitif siswa pada model Project Based Learning bernuansa Etnomatematika. Unnes Journal of Mathematics Education Research, 6(1), 120-129.

Putriari, M. D. (2013). Keefektifan project based learning pada pencapaian kemampuan pemecahan masalah peserta didik kelas X SMK materi program linear. Universitas Negeri Semarang.

Riyanti, M. T., Erwin, T. N., \& Suriani, S. H. (2017). Implementing project based learning approach to graphic design course. Journal of Education and Practice, 8(15), 173177.

Robert M. Gagne, Leslie J. Briggs, W. W. W. (1992). Principles of instructional design. Harcourt Brace Jovenich Colege Publishers.

Setyosari, P. (2014). Menciptakan pembelajaran yang efektif dan berkualitas. JINOTEP: Jurnal Inovasi dan Teknologi Pembelajaran, 1(1).

Solikah, A., \& Himmah, W. I. (2019). Keefektifan model pembelajaran means ends analysis dengan strategi heuristik terhadap kemampuan pemecahan masalah matematika. Hipotenusa: Journal of Mathematical Society, 1(1), 1-8. https://doi.org/10.18326/hipotenusa.v1i1.3278

Sugiyono. (2010). Metode penelitian kuantitatif, kualitatif dan R\&D. Bandung: Alfabeta.

Tong, Y., Kinshuk, \& Wei, X. (2020). Teaching design and practice of a project-based blended learning model. International Journal of Mobile and Blended Learning, 12(1), 33-50. https://doi.org/10.4018/IJMBL.2020010103

Zakiah, N. E., Fatimah, A. T., \& Sunaryo, Y. (2020). Implementasi project-based learning untuk mengeksplorasi kreativitas dan kemampuan berpikir kreatif matematis mahasiswa. Teorema: Teori dan Riset Matematika, 5(2), 285-293. 